\title{
TAYANGAN HIBURAN TV DAN PENERIMAAN BUDAYA POP
}

\author{
Nuryani Tri Rahayu \\ Program Studi Ilmu Komunikasi, \\ FISIP Universitas Veteran Bangun Nusantara \\ J. Letjen S. Humardani No. 1 Jombor Sukoharjo (Jateng) \\ Email: nuryani@yahoo.com
}

\begin{abstract}
ABSTRAK
Penelitian ini bertujuan mendeskripsikan eksposure tayangan hiburan TV, tingkat penerimaan budaya pop, serta menjelaskan efek eksposure tayangan hiburan TV terhadap penerimaan budaya pop oleh pelajar SMA di Kabupaten Sukoharjo. Penelitian ini penting mengingat semakin banyaknya stasiun TV lokal maupun nasional yang menempatkan porsi tayangan hiburan lebih dari $50 \%$ dari seluruh materi maupun jam tayang dengan segmen utama remaja. Tayangan hiburan mengandung muatan budaya pop jauh lebih besar ketimbang budaya lokal dan ini tidak mustahil dapat mempengaruhi kognisi, afeksi, maupun perilaku remaja. Berangkat dari teori komunikasi massa (exposure dan efek), teori budaya, dan teori perilaku, maka dirumuskan hipotesis yang menyatakan bahwa "Eksposure tayangan hiburan TV berpengaruh signifikan terhadap penerimaan budaya pop pada kalangan pelajar SMA di Kabupaten Sukoharjo".Penelitian eksplanatif korelasional ini mengambil lokasi di Kabupaten Sukoharjo dengan populasi pelajar sebanyak 9.798 orang pada 23 SMA dan ditetapkan sebagai sampel dengan cara multi stage cluster sampling sebanyak 79 pelajar. Pengumpulan data menggunakan kuesioner yang telah diuji reliabilitasnya dan pengolahan data menggunakan teknik statistik bivariat Sperman Rhow serta teknik uji signifikansi dengan uji $T$ yang dilakukan melalui bantuan program SPSS versi 11.5. Hasil yang diperoleh menunjukkan bahwa eksposure tayangan hiburan TV oleh kalangan pelajar berada dalam kategori tinggi dengan nilai mean sebesar 82,82 dan standar deviasi sebesar 7,065 dari score terendah 22 dan tertinggi 110. Tingkat penerimaan budaya pop dalam kategori tinggi dengan nilai mean sebesar 78,56 dan standar deviasi sebesar 6,166 dari score terendah 22 dan tertinggi 110. Koefisien pengaruh sebesar 0,777 signifikan pada à sebesar 0,01 sehingga disimpulkan bahwa hipotesis alternatif terbukti atau teruji kebenaran dan keberlakuannya pada taraf kepercayaan 99\%.
\end{abstract}

Kata kunci: Eksposure, tayangan hiburan TV, Budaya pop.

\section{PENDAHULUAN}

Televisi (TV) sering disebut sebagai jendela dunia karena kemampuannya mentransmisikan gambar dan suara secara bersamaan serta mendekati keadaan aslinya. TV sebagai salah satu bentuk media massa telah menjadi suatu kebutuhan masyarakat luas saat ini dan merupakan industri vital yang mempunyai efek luas dalam kehidupan masyarakat dari semua lapisan dan latar belakang sosial. Dalam 
perkembangannya, lembaga pertelevisian dipandang sebagai institusi industri sehingga dalam praktek operasionalnya lebih menekankan aspek bisnis dan lebih berorientasi pada perhitungan cost and benefit. Demikian halnya dengan lembaga TV swasta di Indonesia, lembaga ini tumbuh dan berkembang sebagai institusi komunikasi sekaligus sebagai institusi ekonomi yang bersifat profit oriented (Bharata, 2002:25). Namun demikian, Depari (1995:41) pernah mengingatkan bahwa "media massa sebagai industri tidak dapat didekati dari sisi bisnis atau ekonomi semata karena industri media massa harus memposisikan diri sebagai institusi sosial, institusi politik, dan sekaligus institusi kultural".

Sebagai institusi industri dan institusi kultural, media massa mencakup serangkaian kegiatan produksi informasi dan budaya. Di sini media khususnya TV membuka kemungkinan bagi lahirnya "budaya massa" atau "budaya pop" yaitu produk budaya yang diciptakan semata-mata untuk pasar massa dengan ciri adanya standarisasi produk dan perilaku massa dalam menggunakan produk tersebut (McQuail, 1996:36). Di samping itu, TV juga cenderung "menjajah" baik budaya tinggi maupun budaya rakyat dalam segi isi dan bentuk. Banyak tayangan TV yang berlabel budaya lokal tetapi dalam segi isi maupun bentuk kemasan sajiannya sangat jauh menyimpang dari prinsip-prinsip dan kaidah-kaidah yang terkandung dalam budaya lokal asalnya. Sebagai contoh tari-tarian tradisional dari berbagai daerah, seni batik tulis, dolanan bocah, lelagon, geguritan, dan sebagainya yang semakin langka di masyarakat.

Sampai saat ini di Indonesia telah mengudara secara nasional tidak kurang dari sepuluh stasiun siaran TV swasta, di samping TV pemerintah yang telah beroperasi sebelumnya yakni TVRI. Namun demikian hal tersebut belum diimbangi dengan upaya peningkatan kualitas isi siaran dari segi kultural dalam arti kurang mendukung sosialisasi budaya lokal maupun nasional kepada khalayak. Banyaknya stasiun TV tersebut justru mendorong munculnya persaingan hebat dalam meraih jumlah khalayak penonton melalui program tayangan yang lebih mengacu pada selera massa. Segala daya upaya terus dilakukan stasiun TV guna mendapat sebanyak mungkin simpati penonton termasuk dengan memanfaatkan dunia anak dan remaja. Saat ini TV memiliki potensi besar untuk menjadi media hiburan terpopuler bagi masyarakat dari semua kalangan karena sebagian besar stasiun menyediakan ruang dan porsi paling banyak untuk tayangan hiburan di banding informasi maupun pendidikan. Mengandalkan tayangan hiburan adalah syah karena hal tersebut didasarkan pada fungsi-fungsi sosial yang harus dijalankan namun idealnya fungsi tersebut dijalankan secara seimbang dan proporsional agar efek yang terjadi dapat memenuhi kepentingan media di satu sisi dan kepentingan khalayak di sisi lain. Selain itu, harus pula diingat bahwa TV sebagai media massa dapat menimbulkan efek yang diinginkan maupun yang tidak diinginkan. Sebagai contoh dalam kaitannya dengan budaya, TV yang dalam tayangannya lebih menekankan unsur-unsur budaya modern serta budaya pop, di satu sisi dapat membantu khalayak beradaptasi dengan globalisasi budaya, akan tetapi di sisi lain hal tersebut juga berdampak terhadap terpinggirkannya budaya lokal.

Bagi sebagian besar remaja seusia pelajar Sekolah Menengah Atas (SMA), TV saat ini telah menjadi sahabat ke dua setelah hand phone karena sebagian besar waktu luangnya dihabiskan di depan pesawat TV. Fenomena ini juga dapat dijumpai di kalangan remaja di kabupaten Sukoharjo dimana berbagai atribut kehidupan modern dan budaya pop dapat dengan mudah dilihat baik di rumah, dalam pergaulan masyarakat, maupun di sekolah mulai dari gaya bicara, pakaian, mode rambut, tata 
rias wajah, cara bergaul, aktivitas keseharian, bacaan, tontonan, dan sebagainya. Salah satu faktor perndorong terjadinya hal tersbut adalah letak daerah Kabupaten Sukoharjo yang sangat dekat dengan kota Solo yang telah tumbuh menjadi kota modern dengan tersedianya berbagai vasilitas yang merepresentasikan modernitas, budaya pop, dan kekinian. Meskipun secara sosiologis masyarakat kabupaten Sukoharjo masih menunjukkan karakteristik kehidupan masyarakat pedesaan namun karena akses terhadap berbagai vasilitas di kota tetangganya serta akses terhadap media massa yang sangat terbuka menyebabkan remajanya tumbuh dalam arus yang berbeda, lebih modern dan bahkan cenderung kosmopolit. Remaja terutama yang seusia pelajar SMA lebih banyak menghabiskan waktunya untuk aktivitas yang merepresentasikan kehidupan modern seperti mengikuti berbagai pendidikan tambahan di luar sekolah, jalan-jalan di mall, perawatan tubuh di salon, makan makanan ala luar negeri, nonton film bioskup, main biliar, bergerombol dengan teman sebaya membahas film-film box ofice, lagu-lagu yang sedang tenar, gosip tentang selebritis, dan terutama menonton TV. Fenomena ini lebih tampak jelas pada pelajar SMA karena pada masyarakat khususnya di Kabupaten Sukoharjo terdapat kecenderungan bahwa pelajar SMA secara psikhologis memiliki perasaan sebagai the first class dalam dunia pelajar setingkatnya terutama bila dibanding dengan pelajar sekolah kejuruan.

Berangkat dari berbagai fenomena tersebut maka penelitian ini memfokuskan kajian terhadap permasalahan sejauh mana efek eksposure tayangan hiburan TV terhadap penerimaan budaya pop pada kalangan pelajar SMA di Kabupaten Sukoharjo. Permasalahan ini juga menyangkut bagaimana pola eksposure pelajar SMA terhadap tayangan hiburan TV, dan bagaimana penerimaan nilai-nilai budaya pop oleh remaja yang meliputi pengetahuan, sikap, dan representasinya dalam bentuk perilaku. Asumsinya adalah bahwa semakin tinggi tingkat eksposure tayangan hiburan TV akan semakin nyata pula penerimaan budaya pop oleh kalangan pelajar SMA di Kabupaten Sukoharjo.

\section{TINJAUAN PUSTAKA}

Salah satu pendekatan dalam studi media menurut McQuail (1996:66) adalah pendekatan sosial budaya yang memandang bahwa kebudayaan saling berkaitan erat dengan kegiatan sosial termasuk aktivitas media dan semua kegiatan tersebut merupakan bentuk kegiatan manusia yang berlaku di mana-mana. Di sini setiap media akan membentuk dan memelihara citranya sendiri yang membedakannya dengan media sejenis antara lain melalui dimensi normatif yang mencakup dimensi kenyataan, moral, dan seni.

Sesuai dimensi-dimensi tersebut, TV sering dinilai sebagai media yang kurang serius, tidak mengacu pada budaya tinggi, lebih dekat dengan kenyataan, dan lebih mampu menyajikan kenyataan sekarang (McQuail, 1996:39). Isi yang lazim diproduksi dan disebar luaskan media massa termasuk TV selama berpuluh tahun adalah budaya massa sebagaimana dikemukakan oleh Lukmantoro (2004:28) yang mensarikan pendapat Adorno dan Hoorkheimer bahwa media massa memiliki kemampuan untuk menghasilkan industri budaya yaitu budaya yang sudah mengalami komodifikasi serta industrialisasi, diatur dari atas - kalangan teknisi dan industriawan yang bekerja di media massa -, dan secara esensial diproduksi sematamata untuk memperoleh keuntungan (making profits). Ini berarti media massa 
membuka kemungkinan bagi lahirnya budaya massa atau budaya pop karena media massa seringkali menyerap budaya tersebut untuk kepentingan isi maupun bentuknya.

Budaya pop adalah sesuatu yang diproduksi dengan sangat massif dan dipandang sebagai komoditi. Budaya pop adalah budaya yang disukai banyak orang, budaya massa yang komersial dan membodohi orang banyak (Budiman, 2000:8). Adapun ciri-ciri budaya massa atau budaya pop adalah :

- Institusionalisasi tergantung pada media dan pasar.

- Pengorganisasian dan produksi ditujukan untuk pasar massa dan memanfaatkan teknlogi secara terencana dan terorganisir.

- Isinya dangkal, tidak bermakna ganda, menyenangkan, universal, tapi bisa punah.

- Khalayaknya heterogen dan berorientasi konsumtif.

- Efek yang dihasilkan berupa kesenangan seketika dan pengalihan perhatian.

Sedang menurut McQuail (1996:38), wujud budaya pop beraneka ragam misalnya ; bahasa, busana, musik, tata cara, dan sebagainya. Budaya pop berkaitan erat dengan media massa yang dalam hal ini adalah TV bahkan dapat dikatakan bahwa media massa berperan penting dalam imperialisme budaya sebagaimana teori imperialisme budaya atau imperialisme media yang berasumsi bahwa media dapat membantu modernisasi dengan memperkenalkan "nilai-nilai Barat" dan mengaburkan nilai-nilai tradisional serta hilangnya keaslian budaya lokal. Media menghasilkan pengaruh negatif atau regresif terhadap budaya penerima melalui produk media aktual, tema dan gaya, serta melalui praktek dan nilai-nilai profesional (McQuail (1996:41). Imperialisme budaya oleh media massa dilakukan secara sistematis dengan menjalin hubungan resiprokal antara media dan budaya massa dimana media massa mengeksploitasi mimpi-mimpi khalayak dan mengemasnya untuk kemudian menjualnya kembali kepada khalayak (Budiman, 2000:8). Fungsi ini kemudian dikenal sebagai indusri budaya oleh media massa (culture industry). Dari pernyataan ini dapat dikatakan bahwa industri budaya ditandai oleh adanya komodifikasi, massifikasi, dan standarisasi. (Lukmantoro, 2004:29). Willensky dalam Barrett \& New Bold (1995:88-89) menyatakan bahwa budaya massa mengacu pada produk-produk kultur yang dimanufaktur untuk kepentingan pasar massa. Budaya massa mengandung nilai-nilai dan norma-norma yang melekat pada masyarakat massa dimana kepercayaan dan nilai-nilai politik kulturalnya cenderung homogenous dan berubah-ubah.

Teori masyarakat massa dari Barran dan Davis (2000:39) mendefinisikan konsep tersebut sebagai suatu gagasan bahwa media mempunyai pengaruh buruk yang merusak tatanan sosial melalui pengaruhnya terhadap rata-rata orang yang tak berdaya. Asumsinya antara lain bahwa media dipandang sebagai suatu yang membahayakan, jahat bagaikan kanker sehingga harus dibersihkan atau dilakukan restrukturisasi total serta media memiliki kekuatan menjangkau dan mempengaruhi secara langsung terhadap pemikiran rata-rata orang. Media massa menurunkan nilainilai dan bentuk-bentuk budaya tinggi serta membawa kemunduran peradaban secara umum. Hal ini berarti terdapat interdependensi antara masyarakat massa dan budaya massa yang diciptakan oleh media. Di satu sisi TV merupakan kreator budaya massa, dan di sisi lain khalayak dengan budaya massanya menjadi sumber inspirasi utama penetapan program tayangan TV. Ini berarti bahwa pada media dan dengan 
proses tertentu, isi media dapat menghasilkan efek tertentu pula. Isi media dapat menimbulkan efek pada khalayak apabila khalayak melakukan eksposure terhadap media tersebut.

Eksposure media diartikan sebagai suatu kondisi di mana orang diterpa oleh isi media atau bagaimana isi media menerpa audience. Eksposure media adalah perilaku seseorang atau audience dalam menggunakan media massa. Perilaku ini menurut Blumler dalam Littlejohn (1999:228) dipengaruhi oleh beberapa faktor seperti ; surveillance yaitu kebutuhan individu untuk mengetahui lingkungannya, curiosity yaitu kebutuhan individu untuk mengetahui peristiwa-peristiwa menonjol di lingkungannya, diversion yaitu kebutuhan individu untuk lari dari perasaan tertekan, tidak aman, atau untuk melepaskan ketegangan jiwa, dan personal identity yaitu kebutuhan individu untuk mengenal dirinya dan mengetahui posisi keberadaannya di masyarakat.

Frank Biocca dalam Littlejohn (1999:337) menyatakan bahwa : Karakteristik eksposure media dapat diukur melalui dimensi-dimensi ; selectivity (kemampuan memilih) yaitu kemampuan audience dalam menetapkan pilihan terhadap media dan isi yang akan dieksposenya, intentionally (kesengajaan) yaitu tingkat kesengajaan audience dalam menggunakan media atau kemampuan dalam mengungkapkan tujuan-tujuan penggunaan media, utilitarianism (pemanfaatan) yaitu kemampuan audience untuk mendapatkan manfaat dari penggunaan media, involvement (keterlibatan) yaitu keikut sertaan pikiran dan perasaan audience dalam menggunakan media dan pesan media yang diukur dari frekuensi maupun intensitas, dan previous to influence yaitu kemampuan untuk melawan arus pengaruh media.

Audience yang dalam penelitian ini adalah pelajar SMA memiliki ketergantungan yang tinggi terhadap media massa dimana TV dijadikan sebagai acuan dominan dalam berbagai pengambilan keputusan. Rokeach dan DeFleur (1975:264) menyarankan penggunaan suatu model untuk mengukur ketergantungan khalayak terhadap media yang dikenal dengan dependency model of mass communication effects yang dapat divisualisasikan sebagai berikut:

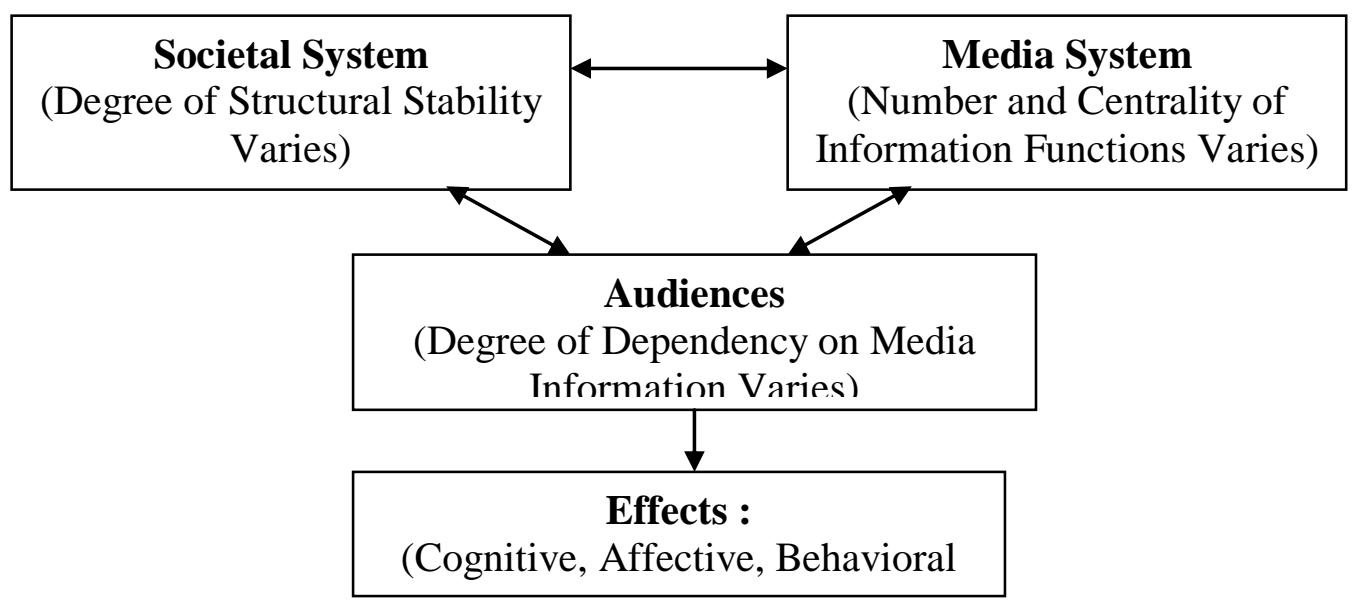

[Society, media, and audience: Reciprocal relationship dari DeFleur dan Rokeach

(1975:264.)] 
Model tersebut berasumsi bahwa sifat dan bentuk pengaruh media massa pada khalayaknya merupakan hasil interaksi tiga variabel yakni ketergantungan khalayak pada media, kondisi struktural masyarakat, dan kondisi atau sistem pelayanan media.

Budaya pop yang mendominasi isi media massa dapat menimbulkan efek dalam arti diciptakan untuk diterima oleh khalayak khususnya remaja. Penerimaan sebagai efek berlangsung mulai dari level kognitif, afektif, dan behavioral atau berupa perubahan pengetahuan, perubahan perasaan atau sikap, dan perubahan perilaku (Chafee dalam Rakhmat 2001:215).

\section{METODE PENELITIAN}

Jenis penelitian yang relefan dengan permasalahan ini adalah eksplanatori korelasional yaitu penelitian yang dimaksudkan untuk menjelaskan hubungan antar variabel dan menguji hipotesis. Populasi penelitian adalah seluruh pelajar kelas I, II, dan III SMA di Kabupaten Sukoharjo baik negeri maupun swasta yang berjumlah 23 SMA, terdiri dari 10 SMA Negeri dengan jumlah pelajar sebanyak 7.966 orang dan tersebar di 8 kecamatan, serta 13 SMA Swasta dengan jumlah pelajar sebanyak 1.832 orang dan tersebar di 7 kecamatan. Jumlah sampel penelitian ditetapkan dengan cara multi stage cluster sampling dengan masing-masing clusternya secara berurutan adalah jumlah SMA di Kabupaten Sukoharjo, jumlah kelas di semua SMA tersebut dan jumlah pelajar di semua kelas diambil secara random. Dari kerangka tersebut diperoleh jumlah sampel sebanyak 79 siswa yang diambil secara random sesuai proporsi masing-masing. Instrumen utama pengumpulan data berupa kuisioner yang reliabilitasnya ditentukan melalui pendekatan konsistensi internal dengan teknik perhitungan menggunakan formula korelasi Pearson (Azwar, 1995:183). Analisis data, uji hipotesis serta uji signifikansinya dilakukan dengan bantuan test statistik bivariat Sperman Rhow melalui vasilitas SPSS versi 11.5

\section{TEMUAN DAN PEMBAHASAN}

\section{Orientasi terhadap TV}

Salah satu faktor yang menentukan penggunaan media TV oleh pelajar adalah pemilikan. Data yang diperoleh menunjukkan bahwa seluruh pelajar yang diamati memiliki pesawat TV di rumah masing-masing baik sebagai TV keluarga (sebanyak 63 atau 79,8\%) ataupun TV pribadi yang berada di dalam kamar sendiri (sebanyak 16 atau 20,2\%). Hal ini mempengauhi aktivitas menontonnya baik dari segi frekuensi, cara menonton, perhatian, maupun penmyediaan waktu khusus. Dari segi frekuansi menonton lebih dari $90 \%$ responden menonton sedikitnya 2 jam setiap hariny dan hanya $6,33 \%$ yang frekuensi menontonnya kurang dari 2 jam per hari. Cara menonton yang paling banyak dilakukan adalah bersama keluarga, sedang perhatian yang dicurahkan rata-rata tidak serius memperhatikan melainkan sambul melakukan aktivitas lain. Sebagian besar pelajar menggunakan waktu luang untuk menonton TV bahkan secara sengaja menyediakan waktu khusus untuk nonton dan hanya 13,93\% responden yang waktu nontonnya tidak tentu. 
Tabel 1. Orientasi Terhadap Televisi

\begin{tabular}{|c|c|c|c|c|c|c|c|c|c|c|}
\hline \multirow[t]{2}{*}{ SCORE } & \multicolumn{2}{|c|}{ PEMILIKAN } & \multicolumn{2}{|c|}{$\begin{array}{l}\text { FREKUENSI } \\
\text { NONTON }\end{array}$} & \multicolumn{2}{|c|}{$\begin{array}{c}\text { CARA } \\
\text { NONTON }\end{array}$} & \multicolumn{2}{|c|}{ PERHATIAN } & \multicolumn{2}{|c|}{$\begin{array}{l}\text { WAKTU } \\
\text { NONTON }\end{array}$} \\
\hline & $\mathbf{F}$ & $\%$ & $\mathbf{F}$ & $\%$ & $\mathbf{F}$ & $\%$ & $\mathbf{F}$ & $\%$ & $\mathbf{F}$ & $\%$ \\
\hline 3 & 16 & 20,2 & 40 & 50,63 & 14 & 17,72 & 37 & 46,84 & 22 & 27,85 \\
\hline 2 & 63 & 79.8 & 34 & 43,04 & 2 & 2,53 & 41 & 51,9 & 46 & 58,22 \\
\hline 1 & 0 & 0 & 5 & 6,33 & 63 & 79,75 & 1 & 1,26 & 11 & 13,93 \\
\hline JMLH & 79 & 100 & 79 & 100 & 79 & 100 & 79 & 100 & 79 & 100 \\
\hline
\end{tabular}

Sumber : Kuisioner No. 6 s/d 10

\section{Eksposure terhadap Tayangan Hiburan TV}

Aktivitas pelajar dalam eksposure terhadap tayangan hiburan TV yang diteliti meliputi lima dimensi yaitu ;

1. Selektivitas

2. Kesengajaan

3. Kemanfaatan

4. Keterlibatan, dan

5. Keyakinan

Secara lengkap data mengenai hal tersebut tampak pada tabel distribusi frekuensi berikut ini.

Tabel 1. Distribusi Frekuensi Variabel Independen Eksposure Tayangan Hiburan TV

\begin{tabular}{|c|c|c|c|c|c|c|c|c|c|c|c|c|}
\hline \multirow{2}{*}{ No } & \multirow{2}{*}{ INDIKATOR / DIMENSI } & \multicolumn{2}{|c|}{5 (SS) } & \multicolumn{2}{|c|}{$4(\mathrm{~S})$} & \multicolumn{2}{|c|}{$3(\mathrm{~N})$} & \multicolumn{2}{|c|}{ 2(TS) } & 1(STS) & \multirow{2}{*}{\multicolumn{2}{|c|}{ Rerata }} \\
\hline & & $\mathbf{F}$ & $\%$ & $\mathbf{F}$ & $\%$ & $\mathbf{F}$ & $\%$ & $\mathbf{F}$ & $\%$ & F $\%$ & & \\
\hline \multicolumn{13}{|c|}{ I $\quad$ SELEKTIVITAS } \\
\hline 1 & TV sebagai sumber utama hiburn & 7 & 8,86 & 48 & 60,76 & & 18,99 & 8 & 10,13 & 11,27 & 3,66 & 3,69 \\
\hline 2 & $\begin{array}{l}\text { Tayangan hiburan TV lebih } \\
\text { menarik }\end{array}$ & 7 & 8,86 & 36 & 45,57 & & 36,71 & 7 & 8,86 & 00,00 & 3,54 & \\
\hline 3 & $\begin{array}{l}\text { TV memberi kelelua-saan memilih } \\
\text { Hiburan }\end{array}$ & 10 & 12,66 & 50 & 63,29 & & 22,78 & 1 & 1,27 & 00,00 & 3,87 & \\
\hline \multicolumn{13}{|c|}{ II KESENGAJAAN } \\
\hline 4 & $\begin{array}{l}\text { Penyempatan waktu untuk } \\
\text { nonton tayangan }\end{array}$ & 22 & 27,85 & 22 & 27,85 & & 39,24 & 4 & 5,06 & 00,00 & 3,78 & 3,70 \\
\hline 5 & $\begin{array}{l}\text { Penggunaan waktu lu-ang untuk } \\
\text { nonton TV }\end{array}$ & 19 & 24,05 & 31 & 39,24 & & 24,05 & 10 & 12,66 & 00,00 & 3,75 & \\
\hline 6 & $\begin{array}{l}\text { Aktivitas nonton tanpa } \\
\text { aktivitas lain }\end{array}$ & 12 & 15,19 & 31 & 39,24 & & 34,18 & 9 & 11,39 & 00,00 & 3,58 & \\
\hline 7 & $\begin{array}{l}\text { Aktivitas nonton dengan } \\
\text { Penuh perhatian }\end{array}$ & 8 & 10,13 & 42 & 53,16 & & 31,65 & 4 & 5,06 & 00,00 & 3,68 & \\
\hline 8 & $\begin{array}{l}\text { Kesengajaan menye-diakan } \\
\text { waktu khusus }\end{array}$ & 17 & 21,52 & 31 & 39,24 & & 25,32 & 11 & 13,92 & 00,00 & 3,68 & \\
\hline \multicolumn{13}{|c|}{ III KEMANFAATAN } \\
\hline 9 & $\begin{array}{l}\text { Memperoleh hal-hal yg } \\
\text { menyenangkan }\end{array}$ & 23 & 29,11 & 40 & 50,63 & & 16,46 & 3 & 3,80 & 00,00 & 4,05 & \\
\hline & $\begin{array}{l}\text { Mengetahui banyak hal } \\
\text { Yang menjadi trend }\end{array}$ & 12 & 15,19 & 44 & 55,70 & & 26,58 & 2 & 2,53 & 00,00 & 3,84 & 3,84 \\
\hline
\end{tabular}




\begin{tabular}{|c|c|c|c|c|c|c|c|c|c|c|c|}
\hline \multirow{2}{*}{ No } & \multirow{2}{*}{ INDIKATOR / DIMENSI } & \multicolumn{2}{|c|}{5 (SS) } & \multicolumn{2}{|c|}{$4(\mathrm{~S})$} & $3(\mathrm{~N})$ & \multicolumn{2}{|c|}{ 2(TS) } & 1(STS) & \multicolumn{2}{|c|}{ Rerata } \\
\hline & & $\mathbf{F}$ & $\%$ & $\mathbf{F}$ & $\%$ & F $\%$ & $\mathbf{F}$ & $\%$ & & Kera & \\
\hline 11 & $\begin{array}{l}\text { Mengetahui bagaimana bisa } \\
\text { tampil trendi }\end{array}$ & 12 & 15,19 & 38 & 48,10 & 2531,65 & 4 & 5,06 & 00,00 & 3,73 & \\
\hline 12 & $\begin{array}{l}\text { Membantu mengikuti } \\
\text { Budaya banyak orang }\end{array}$ & 17 & 21,52 & 36 & 45,57 & 2227,85 & 4 & 5,06 & 00,00 & 3,84 & \\
\hline 13 & $\begin{array}{l}\text { Merasa menjadi bagian } \\
\text { komunitas modern }\end{array}$ & 12 & 15,19 & 40 & 50,63 & 2329,11 & 4 & 5,06 & 00,00 & 3,76 & \\
\hline IV & KETERLIBATAN & & & & & & & & & & \\
\hline 14 & $\begin{array}{l}\text { Diskusi isi tayangan } \\
\text { Dengan teman sekolah }\end{array}$ & 7 & 8,86 & 49 & 62,03 & 1721,52 & 6 & 7,59 & 00,00 & 3,72 & 3,78 \\
\hline 15 & $\begin{array}{l}\text { Berbagi pengalaman } \\
\text { tentang budaya trend }\end{array}$ & 8 & 10,13 & 44 & 55,70 & 2430,38 & 3 & 3,80 & 00,00 & 3,72 & \\
\hline 16 & $\begin{array}{l}\text { Kecewa bila tertinggal } \\
\text { tayangan hiburan }\end{array}$ & 21 & 26,58 & 35 & 44,30 & 1822,78 & 5 & 6,33 & 00,00 & 3,91 & \\
\hline 17 & $\begin{array}{l}\text { Senang punya banyak } \\
\text { Info tentang trend }\end{array}$ & 10 & 12,66 & 44 & 55,70 & 2329,11 & 2 & 2,53 & 00,00 & 3,78 & \\
\hline $\mathrm{V}$ & KEYAKINAN & & & & & & & & & & \\
\hline 18 & $\begin{array}{l}\text { Kebiasaan dlm tayangan } \\
\text { hiburan TV adalah baik }\end{array}$ & 15 & 18,99 & 38 & 48,10 & 2126,58 & 5 & 6,33 & $\overline{0} 0,00$ & 3,80 & 3,7 \\
\hline 19 & $\begin{array}{l}\text { Perasaan tak perlu ban-dingkan } \\
\text { isi tayangan dg nilai sendiri }\end{array}$ & 23 & 29,11 & 34 & 43,04 & 2025,32 & 2 & 2,53 & 00,00 & 3,99 & \\
\hline 20 & $\begin{array}{l}\text { Penggunaan isi tayang-an sbg } \\
\text { acuan tampilan }\end{array}$ & 8 & 10,13 & 46 & 58,23 & 2126,58 & 4 & 5,06 & 00,00 & 3,73 & \\
\hline 21 & $\begin{array}{l}\text { Kebiasaan dlm tayangan tidak } \\
\text { bertentangan dg adapt Jawa }\end{array}$ & 5 & 6,33 & 41 & 51,90 & 2329,11 & 10 & 12,66 & 00,00 & 3,52 & \\
\hline 22 & $\begin{array}{l}\text { Tayangan hiburan sbg } \\
\text { model sikap yang tepat }\end{array}$ & 5 & 6,33 & 45 & 56,96 & 1518,99 & 12 & 15,19 & 22,53 & 3,49 & \\
\hline
\end{tabular}

Dari hasil pengolahan data dapat dijelaskan masing-masing dimensi eksposure sebagai berikut :

a. Selektivitas

Data tersebut menunjukkan bahwa kemampuan responden dalam menetapkan pilihan terhadap media dan isi yang akan dieksposenya berada dalam kategori tinggi. Ini berarti bahwa responden memiliki kebebasan dan mampu menentukan pilihan terhadap media maupun program tayangan yang disukai untuk ditonton. Menurut sebagian besr responden TV merupakan sumber utama untuk mendapatkan hiburan dan memberikan keleluasaan untuk memilih tayangan hiburan yang disukai. Sebagian besar responden juga menganggap bahwa tayangan hiburan TV lebih menarik daripada tayangan lain.

b. Kesengajaan

Dimensi kesengajaan dalam aktivitas eksposure tayangan hiburan TV berada dalam kategori tinggi (rata-rata 3,54) karena sebagian besar responden sengaja menyediakan waktu tersendiri untuk nonton tayangan hiburan TV dan lebih banyak menghabiskan waktu luangnya di depan TV. Dari 5 item kesengajaan, item menonton TV tanpa melakukan aktivitas lain memperoleh nilai rata-rata terendah $(3,58)$ karena sebanyak $45,57 \%$ responden menonton TV sambil melakukan aktivitas lain.

c. Kemanfaatan

Manfaat tayangan hiburan TV untuk mendapatkan pengetahuan mengenai halhal baru yang menyenagkan mencapai katagori tinggi (rata-rta 4,05) karena hampir $80 \%$ responden menyatakan demikian. Selain itu tayangan hiburan juga 
bermanfat untuk mengenal banyak hal yang sedang menjadi trend $(3,84)$, menambah pengetahuan tentang cara tampil gaul $(3,73)$, dan membantu menimbulkan perasaan menjadi bagian dari komunitas modern $(3,76)$.

d. Keterlibatan

Keikut sertaan pikiran dan perasaan responden dalam menggunakan media dan pesan media berada dalam katagori tinggi karena sebagian besar responden sering terlibat dalam diskusi mengenai tayangan hiburan TV dengan teman sekolah dan berbagi pengalaman tentang budaya yang sedang menjadi tren dengan teman. Sebagian besar responden (68\%) senang bila memiliki banyak informasi tentang tren baru untuk diceritakn kepada orang lain, dan lebih dari 70\% responden merasa kecewa bila tidak dapat menonton tayangan hiburan yang disukai di TV.

e. Keyakinan

Dimensi keyakinan sebagai salah satu indikator aktivitas eksposure tayangan hiburan TV oleh pelajar berada dalam katagori tinggi. Dari 5 item pernyataan tentang keyakinan, item percaya bahwa tayangan hiburan TV dapat menjadi model yang tepat bagi sikap dalam bergaul memperoleh nilai mean terendah $(3,49)$ karena hampir $40 \%$ responden tidak setuju pada pernyataan tersebut. Sedang pernyataan bahwa reaponden tidak perlu membandingkan berbagai kebiasaan yang tampak dalam tayangan hiburan TV dengan nilai-nilainya sendiri, keluarga, maupun masyarakat mencapai nilai mean tertinggi $(3,99)$.

Hasil analisis juga menunjukkan nilai mean untuk variabel independen (eksposure tayangan hiburan TV) sebesar 82,82 dari score terendah 22 dan tertinggi 110 dengan standar deviasi sebesar 7,065. Dengan demikian dapat disimpulkan bahwa aktivitas eksposure tayangan hiburan TV oleh pelajar SMA di Kabupaten Sukopharjo dalam katagori tinggi.

\section{Penerimaan Budaya Pop}

Tingkat penerimaan budaya pop oleh pelajar SMA di Kabupaten Sukoharjo yang diukur melalui dimensi-dimensi pengetahuan, sikap, dan perilaku diperoleh hasil sebagai berikut.

Tabel 3. Distribusi Frekuensi Ariabel Dependen Penerimaan Budaya POP

\begin{tabular}{|c|c|c|c|c|c|c|c|c|c|c|c|c|c|}
\hline \multirow{2}{*}{ No } & \multirow{2}{*}{ INDIKATOR / DIMENSI } & \multicolumn{2}{|c|}{5 (SS) } & \multicolumn{2}{|c|}{$4(\mathrm{~S})$} & \multicolumn{2}{|c|}{$3(\mathrm{~N})$} & \multicolumn{2}{|c|}{2 (TS) } & \multicolumn{2}{|c|}{1 (STS) } & \multirow{2}{*}{\multicolumn{2}{|c|}{ Rerata }} \\
\hline & & $\mathbf{F}$ & $\%$ & $\mathbf{F}$ & $\%$ & $\mathbf{F}$ & $\%$ & $\mathbf{F}$ & $\%$ & $\mathbf{F}$ & $\%$ & & \\
\hline & & & & & & & & & & & & & \\
\hline 1 & $\begin{array}{l}\text { Penyesuaian dg kebiasaan } \\
\text { banyak orang }\end{array}$ & 3 & 3,797 & 45 & 56,96 & 25 & 31,6 & 6 & 7,59 & 0 & 0 & 3,57 & \\
\hline 2 & $\begin{array}{l}\text { Kebiasaan banyak orng adalah } \\
\text { baik }\end{array}$ & 0 & 0 & 45 & 56,96 & 23 & 29,1 & 8 & 10,1 & 3 & 3,8 & 3,39 & \\
\hline 3 & $\begin{array}{l}\text { Tampilan tidak sesuai trend } \\
\text { berarti kuno }\end{array}$ & 2 & 2,532 & 53 & 67,09 & 18 & 22,8 & 4 & 5,06 & 2 & 2,5 & 3,62 & 3,8 \\
\hline 4 & $\begin{array}{l}\text { Makan, nonton, jalan-jalan } \\
\text { berarti modern }\end{array}$ & 13 & 16,46 & 56 & 70,89 & 6 & 7,59 & 2 & 2,53 & 2 & 2,5 & 3,96 & \\
\hline 5 & Kehidupan modern bukan hanya & & & & & & & & & & & & \\
\hline & milik orang kaya & 23 & 29,11 & 47 & 59,49 & 9 & 11,4 & 0 & 0 & 0 & 0 & 4,18 & \\
\hline 6 & Perilaku mirip artis sudah jadi & 25 & 31,65 & 36 & 45,57 & 17 & 21,5 & 1 & 1,27 & 0 & 0 & 4,08 & \\
\hline
\end{tabular}




\begin{tabular}{|c|c|c|c|c|c|c|c|c|c|c|c|c|c|}
\hline \multirow{2}{*}{ No } & \multirow{2}{*}{ INDIKATOR / DIMENSI } & \multicolumn{2}{|c|}{5 (SS) } & \multicolumn{2}{|c|}{$4(\mathrm{~S})$} & \multicolumn{2}{|c|}{$3(\mathrm{~N})$} & \multicolumn{2}{|c|}{2 (TS) } & \multicolumn{2}{|c|}{1 (STS) } & \multirow{2}{*}{\multicolumn{2}{|c|}{ Rerata }} \\
\hline & & $\mathbf{F}$ & $\%$ & $\mathbf{F}$ & $\%$ & $\mathbf{F}$ & $\%$ & $\mathbf{F}$ & $\%$ & $\mathbf{F}$ & $\%$ & & \\
\hline & kebiasaan orang banyak & & & & & & & & & & & & \\
\hline II & SIKAP & & & & & & & & & & & & \\
\hline 7 & $\begin{array}{l}\text { Kesukaan pada pelajar yang } \\
\text { tampil mirip artis }\end{array}$ & 20 & 25,32 & 32 & 40,51 & 19 & 24,1 & 2 & 2,53 & 6 & 7,6 & 3,73 & \\
\hline 8 & $\begin{array}{l}\text { Ketidaksukaan pada pelajar } \\
\text { yg tak ikuti trend }\end{array}$ & 20 & 25,32 & 39 & 49,37 & 17 & 21,5 & 3 & 3,8 & 0 & 0 & 3,96 & \\
\hline 9 & $\begin{array}{l}\text { Ketidaksukaan pada orang } \\
\text { yang mengkritik tampilan }\end{array}$ & 7 & 8,86 & 45 & 56,96 & 26 & 32,9 & 1 & 1,27 & 0 & 0 & 3,73 & \\
\hline $\begin{array}{l}10 \\
11\end{array}$ & $\begin{array}{l}\text { Arti penting mengikuti trend } \\
\text { Remaja tak perlu bantu orang }\end{array}$ & 7 & 8,86 & 49 & 62,03 & 20 & 25,3 & 3 & 3,8 & 0 & 0 & 3,76 & 3,7 \\
\hline & tua bekerja & 9 & 11,39 & 43 & 54,43 & 17 & 21,5 & 2 & 2,53 & 8 & 10 & 3,54 & \\
\hline 12 & $\begin{array}{l}\text { Remaja berbicara santun berarti } \\
\text { tak modern }\end{array}$ & 3 & 3,79 & 44 & 55,7 & 23 & 29,1 & 9 & 11,4 & 0 & 0 & 3,52 & \\
\hline $\begin{array}{l}13 \\
14\end{array}$ & $\begin{array}{l}\text { Arti penting percaya diri dalam } \\
\text { tampilan } \\
\text { Bacaan hiburan lebih baik dari }\end{array}$ & 13 & 16,46 & 40 & 50,63 & 24 & 30,4 & 2 & 2,53 & 0 & 0 & 3,81 & \\
\hline & lainnya & 6 & 7,59 & 45 & 56,96 & 23 & 29,1 & 5 & 6,33 & 0 & 0 & 3,66 & \\
\hline III & PERILAKU & & & & & & & & & & & & \\
\hline 15 & $\begin{array}{l}\text { Kesukaan pd tontonan yg } \\
\text { menyenangkan }\end{array}$ & 11 & 13,92 & 44 & 55,7 & 22 & 27,8 & 2 & 2,53 & 0 & 0 & 3,81 & \\
\hline 16 & $\begin{array}{l}\text { Usaha tampil trendi dalam } \\
\text { pergaulan }\end{array}$ & 6 & 7,59 & 42 & 53,16 & 28 & 35,4 & 3 & 3,8 & 0 & 0 & 3,65 & \\
\hline 17 & $\begin{array}{l}\text { Aktivitas mengikuti pilihan } \\
\text { banyak orang }\end{array}$ & 3 & 3,79 & 45 & 56,96 & 22 & 27,8 & 8 & 10,1 & 1 & 1,3 & 3,52 & \\
\hline $\begin{array}{l}18 \\
19\end{array}$ & Keseringan jalan-jalan ke mall & 6 & 7,59 & 29 & 36,71 & 23 & 29,1 & 15 & 19 & 6 & 7,6 & 3,18 & 3,2 \\
\hline & Keseringan nonton di bioskup & 3 & 3,797 & 28 & 35,44 & 19 & 24,1 & 25 & 31,6 & 4 & 5,1 & 3,01 & \\
\hline 20 & $\begin{array}{l}\text { Keseringan mencoba menu } \\
\text { makanan LN }\end{array}$ & 1 & 1,26 & 31 & 39,24 & 22 & 27,8 & 24 & 30,4 & 1 & 1,3 & 3,09 & \\
\hline 21 & $\begin{array}{l}\text { Aktivitas mengikuti mode } \\
\text { rambut artis }\end{array}$ & 0 & 0 & 46 & 58,23 & 26 & 32,9 & 7 & 8,86 & 0 & 0 & 3,49 & \\
\hline 22 & $\begin{array}{l}\text { Aktivitas mengecat rambut } \\
\text { walau dilarang }\end{array}$ & 0 & 0 & 3 & 3,79 & 16 & 20,3 & 42 & 53,2 & 18 & 23 & 2,05 & \\
\hline
\end{tabular}

Sumber : Kuesioner II No. 1 s/d 22 yang diolah.

a. Pengetahuan

Salah satu bentuk efek komunikasi massa adalah efek kognitif atau terjadinya perubahan pengetahuan audience. Dimensi yang diukur melalui 6 item pernyataan ini, 5 diantaranya mencapai rata-rata dalam kagori tinggi dan 1 lainnya dalam kategori cenderung sangat tinggi. Lebih dari 80\% responden menyatakan setuju bahwa kehidupan modern bukan milik orang-orang kaya atau orang kota saja. Menurut responden, orang desapun harus tampil trendi. Sebagian besar responden juga setuju bahwa mengecat rambut, merawat diri di salon, mengenakan baju dan sepatu seperti artist sudah menjadi kebiasaan banyak orang. Hal ini menunjukkan bahw pengetahuan responden mengenai budaya pop dalam katagori tinggi.

b. Sikap

Sikap responden terhadap budaya pop cenderung mendukung, menyetujui, atau menerima yang ditunjukkan dengan nilai mean untuk dimensi sikap seluruhnya 
dalam katagori tinggi. Sebagian besar responden menyetujui pelajar yang tampil seperti artist apapun latar belakang sosialnya dan tidak menyukai pelajar atau remaja yang tidak mengikuti trend mode sekarang, serta tidak suka bila ada orang yang mengkritik tampilan pelajar atau remaja yang meniru artist. Sebagian besar responden juga menyetujui bahwa mengikuti trend adalah penting agar bisa dianggap sebagai orang modern dan bahwa dalam penampilan yang penting percaya diri meskipun kurang pas dengan situasi dan kondisi.

c. Perilaku

Penerimaan terhadap budaya pop yang berupa perilaku juga berada dalam katagori tinggi. Dari 8 item pernyataan perilaku, hanya 1 yang berada dalam katagori sedang $(2,05)$ karena sebagain besar responden $(76 \%)$ tidak setuju bila pelajar tetap mengecat rambut meskipun orang tua atau pihak sekolah melarang. Meskipun demikian mode rambut sebagian besar responden (58,23\%) mengikuti trend mode rambut para artist sinetron di TV dan hanya $22,78 \%$ responden saja yang tidak meniru. Sebagian besar responden (60\%) pilihan pakaian, asesori, dan make upnya mengikuti trend mode yang dipilih banyak orang sekarang.

Selain itu diketahui pula bahwa nilai mean variabel dependen atau penerimaan budaya pop oleh pelajar SMA di Kabupaten Sukoharjo sebesar 78,56 dari score terendah 22 dan tertinggi 110 dengan standar deviasi sebesar 6,166. Dengan demikian dapat disimpulkan bahwa tikat penerimaan budaya pop oleh pelajar SMA di Kabupaten Sukoharjo dalam katagori tinggi.

Dari hasil pengolahan data dengan bantuan test statistik diketahui bahwa pengaruh tayangan hiburan TV terhadap penerimaan budaya pop adalah signifikan dengan koefisien korelasi sebesar 0,777. Angka ini signifikan baik pada level 0,05 maupun 0,01 yang berarti signifikan pada taraf kepercayaan 95\% maupun $99 \%$. Dengan demikian asumsi yang menyatakan bahwa eksposure tayangan hiburan TV berpengaruh signifikan terhadap penerimaan budaya pop oleh pelajar SMA di Kabupaten Sukoharjo dapat diterima keberlakuannya atau dapat diuji kebenarannya pada taraf kepercayaan $99 \%$ atau $\alpha=0,01$

\section{KESIMPULAN DAN SARAN}

Dari hasil analisis data mengenai tayangan hiburan TV dan penerimaan budaya pop dapat ditarik kesimpulan sebagai berikut:

1. Eksposure tayangan hiburan TV yang dilakukan oleh pelajar SMA di Kabupaten Sukoharjo dalam kategori tinggi dengan rata-rata score sebesar 82,82 dan standar deviasi sebesar 7,065.

2. Penerimaan budaya pop oleh pelajar SMA di Kabupaten Sukoharjo dalam kategori tinggi dengan rata-rata score sebesar 78,56 dan standar deviasi sebesar 6,166 .

3. Test statistik menunjukkan bahwa Eksposure tayangan hiburan TV berpengaruh signifikan terhadap penerimaan budaya pop oleh pelajar SMA di Kabupaten Sukoharjo dengan koefisien korelasi sebesar 0,777 dan uji signifikansi menunjukkan bahwa angka tersebut signifikan pada level 0,01 atau tingkat kepercayaan 99\%. 
4. Hipotesis yang diajukan dinyatakan diterima atau terbukti kebenaran dan keberlakuannya pada taraf kepercayaan $99 \%$ atau $\alpha=0,01$.

Berdasarkan hasil temuan tersebut peneliti menyampaikan beberapa saran sebagai berikut :

1. Pihak sekolah agar menetapkan peraturan yang tegas menyangkut perilaku siswa yang merupakan ekspresi penerimaan budaya pop seperti dalam berpakaian, make up, asesoris, dan sebagainya di sekolah.

2. Pihak sekolah agar memberikan porsi lebih banyak terhadap sosialisasi budaya lokal dan nilai-nilai budi pekerti luhur dalam berbagai bentuk baik berupa pelajaran intra kurikuler maupun berupa kegiatan ekstra kurikuler.

3. Peneliti berikutnya perlu mengkaji lebih jauh faktor-faktor lain yang turut mempengaruhi penerimaan budaya pop oleh remaja.

\section{DAFTAR PUSTAKA}

Azwar, Syaifudin. (1995), Reliabilitas dan Validitas Internal dan Komputasi. Yogyakarta. Liberty.

Barran, Stanley J. Dan Dennis K. Davis. (2000), Mass Communication Theory.; Foundation, Ferment, and Future. 2nd Edition. Canada. Wadsworth.

Barrat, Oliver Boyd dan Chris Newbold. (1995), Approaches to Media ; A Reader. London. Arnold.

Bharata, Bonaventura Satya. (2002) : Komunikasi Iklan Media TV Swasta di Indonesia. Dalam Jurnal ISIP Vol. 3/No.4/Desember 2001-Februari 2002. Yogyakarta. Universitas Atma Jaya.

Budiman, Maneke. (2000), Budaya Populer sebagai Perlawanan Perempuan. Dalam Jurnal Perempuan. Edisi XIII/Maret-2000. Jakarta. Yayasan Jurnal Perempuan.

Depari, Eduard. (1995), Kekerasan di Televisi. Dalam Jurnal ISKI /No. 7-8/Juni 1995. Jakarta. ISKI.

Irwanto, dkk. (1996), Psikologi Umum: Buku Panduan Mahasiswa. Jakarta. Gramedia Pustaka Utama.

Littlejohn, Stephen W. (1999), Theories of Human Communication. 6thEdition. Belmont CA. Wadsworth Publishing Company.

Lukmantoro, Triyono. (2004), Ritual Hari Raya Agama ; Konsumsi Massa dan Khotbah Industri Budaya. Dalam Jurnal Ilmu Komunikasi. Vol. 1 No. 1 Juni/2004. Yogyakarta. Program Studi Ilmu Komunikasi FISIP UAJ.

McQuail, Denis. (1996), Teori Komunikasi Massa Suatu Pengantar. Alih bahasa oleh Agus Dharma dan Aminudin Ram. Jakarta. Erlangga.

Nasir, Moh.. (1988), Metode Penelitian. Jakarta. Ghalia Indonesia. 
Rakhmat, Jalalludin. (2001) : Psikologi Komunikasi. Bandung. Remaja Rodsa Karya.

Rokeach, Sandra Ball. Dan Melvin DeFleur. (1975), Theories of Mass Communication. New York. David McCay.

Sarwono, Sarlito Wirawan. (1986), Pengantar Umum Psikologi. Jakarta. Bulan Bintang.

Setiawan, Suryatin. (1998), Industri Informasi Masa Depan. Dalam Jurnal ISKI No. 4/Mei/1998. Jakarta. ISKI.

Severin, Werner J. Dan James W. Tankard. (1992), Communication Theories ; Origins, Methods. Uses. New York. Hastings House Publisher.

Tomagola, Tamrin Amal. (2000), Popular Culture, Kapitalisme dan Patriarki sangat Terkait. Dalam Jurnal Perempuan Edisi XIII/Maret - 2000. Jakarta. Yayasan Jurnal Perempuan.

Zubaedi. (2005), Mengontrol Tayangan TV. Semarang. Suara Merdeka Edisi 17 Februari 2005. 